\title{
Metals transfer from tobacco to cigarette smoke: Evidences in smokers' lung tissue
}

\author{
Edgar Pinto ${ }^{\mathrm{a}, \mathrm{b}}$, \\ Mariana Cruza \\ Patrícia Ramos ${ }^{\text {, }}$ \\ Agostinho Santos ${ }^{c, d}$ \\ Agostinho Almeida ${ }^{a}$
}

\footnotetext{
a LAQV/REQUIMTE, Department of Chemical Sciences, Laboratory of Applied Chemistry, Faculty of Pharmacy, University of Porto, Porto, Portugal

${ }^{\mathrm{b}}$ Department of Environmental Health, Polytechnic Institute of Porto, School of Health, CISA/Research Center in Environment and Health, Porto, Portugal ${ }^{c}$ National Institute of Legal Medicine and Forensic Sciences-North Branch, Porto, Portugal

${ }^{\mathrm{d}}$ Faculty of Medicine, University of Porto, Porto, Portugal
}

Tobacco use kills millions of people every year around the world. The current level of 11 metals in tobacco was determined and their transfer rate to cigarette smoke was calculated as the difference between the total metal content in cigarettes and the amount present in its ashes. The metals content was also determined in the lung tissue of smokers and non-smokers in order to evaluate the marks that smoking leaves in this tissue. Metals content in tobacco ranged from less than $1 \mu \mathrm{g} / \mathrm{g}$ ( $\mathrm{Co}, \mathrm{Cd}, \mathrm{Pb}, \mathrm{As}$ and $\mathrm{Tl}$ ) to several hundreds of $\mu \mathrm{g} / \mathrm{g}$ ( $\mathrm{Al}$, Mn and $\mathrm{Ba}$ ). The highest transfer rate from tobacco to cigarette smoke was found for $\mathrm{Tl}(85-92 \%)$ and $\mathrm{Cd}(81-90 \%)$, followed by $\mathrm{Pb}(46-60 \%)$ and As (33-44\%). Significantly higher levels of $\mathrm{As}, \mathrm{Cd}$ and $\mathrm{Pb}$ were found in the lung tissue of smokers compared to non-smokers, showing that smoking results in an increase of these metals in the lungs and that they contribute to the carcinogenic potential of cigarette smoke. This study presents important data on current metals content in tobacco and its transference to cigarette smoke and provides evidence of their accumulation in smokers' lung tissue.

Keywords: ICP-MS Lungs Smoking Cigarette Metals 


\section{Introduction}

Tobacco use continues to kill millions of people around the world, with cigarettes being the most widely used tobacco product. Nowadays, about $12 \%$ of all deaths among adults aged 30 years and over are attributed to tobacco [1]. It is estimated that globally tobacco kills around 6 million people each year: five million from direct tobacco smoking while 600,000 deaths are attributable to second-hand smoke effects [2]. On current smoking trends, the annual death toll from tobacco is expected to rise to around 10 million people by 2030 [3].

Smoking negatively impacts on health across the life-course and dramatically reduces both quality of life and life expectancy. The negative impacts of tobacco smoking includes, among others, increased rates of cardiovascular-related death (e.g., ischemic heart disease and stroke) [4], high rates of cancers (especially lung cancer), and death associated with diseases of the respiratory system, including tuberculosis and pneumonia [5].

Direct tobacco smoking and involuntary smoking (exposure to secondhand smoke) have been classified by the International Agency for Research on Cancer (IARC) as agents considered carcinogenic to humans (classified as group 1 exposure circumstances) [6]. Tobacco smoke is a complex and dynamic chemical mixture. Researchers have estimated that tobacco smoke contains more than 7000 chemical compounds from many different classes. Thus, tobacco smoke can be an important source of known toxic compounds such as nitrosamines, polycyclic aromatic hydrocarbons (PAHs), pesticides, heterocyclic and aromatic amines and metals [7]. Among the many harmful and toxic compounds found in tobacco and tobacco smoke, metals seem to play an important role in the overall hazard $[8,9]$. As with all plants, tobacco plants require several nutrients to sustain their physiological functions, which they acquire from the soil. However, both essential and toxic elements can enter and accumulate in plant tissues $[10,11]$. Thus, the main source of metals in tobacco plant is the soil.

Among metals, the most commonly associated with health effects are arsenic (As), ${ }^{1}$ cadmium (Cd), chromium (Cr), nickel (Ni) and lead $(\mathrm{Pb})$. As, $\mathrm{Cd}$ and $\mathrm{Ni}$ are classified as Group 1 carcinogens for humans by IARC [12-14]. Chromium, in its hexavalent oxidation state, is also a Group 1 carcinogen [15]. Inorganic $\mathrm{Pb}$ have been classified in Group 2A ("probably carcinogenic") by IARC [16]. Thus, most available literature focus on the content of these elements in both tobacco and cigarette smoke [17-20]. Despite that, several other metals such as cobalt (Co), manganese (Mn), zinc ( $\mathrm{Zn})$, antimony ( $\mathrm{Sb}$ ) and beryllium (Be) are also present in tobacco and cigarette smoke and can contribute to the harmful effect of smoking.

Virtually, all metals present in tobacco may transfer at some extent into cigarette smoke, and this transfer into both mainstream and sidestream smoke has been of particular interest in the last decades $[8,20,21]$. More recently, the hot topic of metal transfer has been also studied in the case of electronic cigarettes, which are promoted as safer alternatives to conventional cigarettes [22,23]. The extent of which a metal transfer from tobacco to cigarette smoke varies greatly depending on several factors such as the metal properties, metal content in the tobacco, cigarette design, rod length and diameter, filter type, ventilation, among others. [7,8,17].

The aims of this study were: (1) to determine the current levels of several metals in tobacco; (2) to calculate the transfer rate of metals from tobacco to cigarette smoke; and (3) to look for evidences of smoking habits in lung tissue (to establish a link between smoking and metals content in lung tissue). The transfer rate of

\footnotetext{
1 Actually, arsenic is a semi-metal (or metalloid), however for convenience of writing the word "metals" is used to refer all the studied elements.
}

metals from tobacco to cigarette smoke was calculated as the difference between the total metal content in cigarettes and the amount present in its ashes.

\section{Materials and methods}

\section{Cigarette samples}

Packs of twenty (20) different cigarette brands were purchased from retail outlets at Oporto city, Portugal, in 2014. These brands represent the 20 best-selling cigarette brands in the country. Samples were kept in their original packaging until analysis.

\section{Lung tissue samples}

Lung tissues samples were collected from men $(n=37)$ and women $(n=25)$ not registered in the Portuguese National Registry of Refusal to Organ Donation database and complying with all the current regulations regarding human tissue collection for scientific research purposes.

Samples were obtained from individuals submitted to forensic autopsy exams during the year of 2013 and 2014 at the North Branch (Porto) of the Portuguese National Institute of Legal Medicine and Forensic Sciences. A fragment of ca. $1 \mathrm{~cm}^{3}$ was collected from the superior lobe of the right lung and placed in decontaminated polypropylene tubes. Samples were thoroughly rinsed with ultrapure water to completely remove biological fluids and then stored at $-4{ }^{\circ} \mathrm{C}$.

\section{Reagents}

High purity $\mathrm{HNO}_{3}\left(\geq 69 \% \mathrm{w} / \mathrm{w}\right.$, TraceSELECT ${ }^{\circledR}$, Fluka, France), HF (47-51\% v/v, TraceSELECT ${ }^{\circledR}$, Fluka, Germany) and boric acid (99.999\% trace metal basis, Aldrich, St. Louis, MO) were used as received. Calibration standards were prepared from a $10 \mathrm{mg} / \mathrm{L}$ multi-element ICP-MS standard solution (PlasmaCAL SCP-33-MS, SCP Science, Baie-d'Urfé, Quebec, Canada). The internal standards solution was prepared by appropriate dilution of the AccuTrace $^{\mathrm{TM}}$ (AccuStandard ${ }^{\circledR}$, New Haven, CT) ICP-MS-200.8-IS-1 solution $(100 \mathrm{mg} / \mathrm{mL}$ of $\mathrm{Sc}, \mathrm{Y}, \mathrm{In}, \mathrm{Tb}$ and $\mathrm{Bi}$ ). All solutions were prepared using ultrapure water $\left(>18.2 \mathrm{M} \Omega . \mathrm{cm}\right.$ at $\left.25^{\circ} \mathrm{C}\right)$ obtained with a Sartorius (Goettingen, Germany) Arium ${ }^{\circledR}$ pro water purification system.

\section{Tobacco samples preparation}

Two cigarettes from each brand were dried in decontaminated plastic containers for a minimum of $24 \mathrm{~h}$ at $105^{\circ} \mathrm{C}$. Then, the filter was removed and the dried tobacco was manually crushed, homogenized and stored in tightly sealed polypropylene tubes until further analysis. Tobacco samples were solubilized by closed-vessel microwave assisted acid digestion in a MLS-1200 Mega (Sorisole, Italy) microwave oven according to Fresquez et al. [19]. Briefly, samples (ca. $200 \mathrm{mg}$ ) were directly weighted into the polytetrafluorethylene (PTFE) microwave oven vessels and $5 \mathrm{~mL}$ of high-purity concentrated $\mathrm{HNO}_{3}$ was added. The microwave heating program was set to reach the temperature of $200^{\circ} \mathrm{C}$ in $4 \mathrm{~min}$, followed by a 3 min digestion at $200^{\circ} \mathrm{C}$. After cooling, sample solutions were transferred into $25 \mathrm{~mL}$ decontaminated polypropylene volumetric flasks, $5 \mathrm{~mL}$ of $\mathrm{HF}(5 \% \mathrm{v} / \mathrm{v})$ were added and the volume was madeup with ultra-pure water. Sample blanks were obtained using the same procedure. Each sample was digested in triplicate. 
Cigarettes ash samples preparation

Cigarettes were submitted to a simulated smoking procedure. Each cigarette was burned by drawing air through the cigarette with a pipette bulb. During the procedure, the ashes produced were collected into decontaminated polypropylene tubes. Ashes were then solubilized by closed-vessel microwave assisted acid digestion in the same equipment mentioned above according to Hepp, Mindak and Cheng [24]. Cigarette ashes (ca. $100 \mathrm{mg}$ ) were directly weighted into the PTFE microwave oven vessels and $7 \mathrm{~mL}$ of highpurity $\mathrm{HNO}_{3}$ and $2 \mathrm{~mL}$ of high-purity $\mathrm{HF}$ were added. The samples were heated for $15 \mathrm{~min}$ at $130^{\circ} \mathrm{C}$ and held at that temperature for three minutes. Then, the temperature was ramped to $200^{\circ} \mathrm{C}$ in $15 \mathrm{~min}$ and kept at $200^{\circ} \mathrm{C}$ for $30 \mathrm{~min}$. The vessels were allowed to cool and $30 \mathrm{~mL}$ of $4 \%(\mathrm{w} / \mathrm{v})$ boric acid solution was added. The samples were heated again in the microwave to $170^{\circ} \mathrm{C}$ in $15 \mathrm{~min}$ and kept for $10 \mathrm{~min}$ at this temperature. After cooling, sample solutions were transferred into $50 \mathrm{~mL}$ decontaminated polypropylene volumetric flasks and the volume was made-up with ultra-pure water. Sample blanks were obtained using the same procedure. Each sample was digested in triplicate.

\section{Samples analysis}

Multi-elemental analysis was performed using an $\mathrm{iCAP}^{\mathrm{TM}} \mathrm{Q}$ (Thermo Fisher Scientific, Bremen, Germany) ICP-MS instrument equipped with a MicroMist ${ }^{\mathrm{TM}}$ nebulizer, a Peltier-cooled baffled cyclonic spray chamber, a standard quartz torch and a twocone interface design (sample and skimmer cones). High-purity (99.9997\%) argon (Gasin II, Leça da Palmeira, Portugal) was used as the nebulizer and plasma gas. The ICP-MS was operated under the following conditions: RF power, $1550 \mathrm{~W}$; argon flow rate, $14 \mathrm{~L} / \mathrm{min}$; auxiliary argon flow rate, $0.8 \mathrm{~L} / \mathrm{min}$; nebulizer flow rate, $0.98 \mathrm{~L} / \mathrm{min}$. The following elemental isotopes $(\mathrm{m} / \mathrm{z}$ ratios) were monitored for analytical determinations: ${ }^{27} \mathrm{Al},{ }^{52} \mathrm{Cr},{ }^{55} \mathrm{Mn},{ }^{59} \mathrm{Co},{ }^{60} \mathrm{Ni},{ }^{66} \mathrm{Zn},{ }^{75} \mathrm{As}$, ${ }^{111} \mathrm{Cd},{ }^{135} \mathrm{Ba},{ }^{205} \mathrm{Tl}$ and ${ }^{208} \mathrm{~Pb}$; the elemental isotopes ${ }^{45} \mathrm{Sc},{ }^{89} \mathrm{Y},{ }^{115} \mathrm{In}$ and ${ }^{159} \mathrm{~Tb}$ were monitored as internal standard. The limits of detection (LOD) were calculated as the concentration corresponding to 3 times the standard deviation of 10 replicate measurements of the digested sample blanks and are presented in Supplementary material (Table S1).

\section{Estimation of metals transfer from tobacco to cigarette smoke}

The rate of metals transfer from tobacco to cigarette smoke was calculated according to the following equation:

$M T=\frac{M_{\text {Cigarette }}-M_{\text {Ash }}}{M_{\text {Cigarette }}} \times 100$

where MT is the metal transfer in percentage (\%), $\mathrm{M}_{\text {Cigarette }}$ is the metal content in tobacco ( $\mu \mathrm{g} / \mathrm{g}$ of cigarette, dry weight) and $\mathrm{M}_{\mathrm{Ash}}$ is the metal content in the ash ( $\mu \mathrm{g} / \mathrm{g}$ of cigarette, dry weight).

\section{Analytical quality control}

For analytical quality control purposes, the following certified reference materials (CRM) were used: BCR 679 (white cabbage), BCR 176R (fly ash), BCR 667 (estuarine sediment), BCR 723 (road dust)-all supplied by EC Institute for Reference Materials and Measurements (Geel, Belgium). The BCR 679 was analyzed under the same conditions as cigarette samples while BCR 176R, BCR 667 and BCR 723 were analyzed under the same conditions as cigarette ashes. The results obtained in the CRM analysis are presented in Table S2 (Supplementary material).
Table 1

Metals content of tobacco ( $\mu \mathrm{g} / \mathrm{g}$, dry weight).

\begin{tabular}{|c|c|c|c|}
\hline Element & Range $^{\mathrm{a}}$ & $\begin{array}{l}\text { Literature data } \\
\text { (range) }\end{array}$ & Reference \\
\hline \multirow{2}{*}{$\mathrm{Al}$} & \multirow{2}{*}{ 458.6-904.7 (mean: 667.2) } & $699-1200$ & [21] \\
\hline & & $333-546$ & [25] \\
\hline \multirow[b]{2}{*}{ As } & \multirow{2}{*}{$0.08-0.20$ (mean: 0.14 ) } & $0.22-0.36$ & [19] \\
\hline & & $0.06-2.07$ & [17] \\
\hline \multirow[t]{2}{*}{$\mathrm{Ba}$} & \multirow[t]{2}{*}{ 102.3-169.6 (mean: 123.0) } & $40.7-56.6$ & [21] \\
\hline & & $0.19-4.67$ & [17] \\
\hline \multirow[t]{2}{*}{$\mathrm{Cd}$} & \multirow[t]{2}{*}{ 0.49-1.42 (mean: 0.79) } & $1.0-1.7$ & [19] \\
\hline & & $1.66-2.96$ & [25] \\
\hline \multirow{2}{*}{ Co } & \multirow{2}{*}{$0.61-1.08$ (mean: 0.84 ) } & $0.44-1.11$ & [19] \\
\hline & & $<0.01-0.94$ & [21] \\
\hline \multirow{2}{*}{$\mathrm{Cr}$} & \multirow{2}{*}{$0.74-2.52$ (mean: 1.39$)$} & $1.3-3.2$ & [19] \\
\hline & & $<0.1-3.45$ & [21] \\
\hline \multirow{2}{*}{ Mn } & \multirow{2}{*}{ 107.7-179.0 (mean: 148.4) } & $131-245$ & [19] \\
\hline & & $155-400$ & [21] \\
\hline \multirow{3}{*}{$\mathrm{Ni}$} & \multirow{3}{*}{ 1.49-2.65 (mean: 2.10 ) } & $2.1-3.9$ & [19] \\
\hline & & $<2-400$ & [21] \\
\hline & & $0.18-4.63$ & [17] \\
\hline \multirow[t]{2}{*}{$\mathrm{Pb}$} & \multirow[t]{2}{*}{$0.44-0.72$ (mean: 0.55 ) } & $0.60-1.16$ & [19] \\
\hline & & $0.40-1.39$ & [25] \\
\hline $\mathrm{Tl}$ & 0.046-0.104 (mean: 0.074 ) & - & - \\
\hline $\mathrm{Zn}$ & 18.6-30.7 (mean: 25.2) & $16.8-30.5$ & [21] \\
\hline
\end{tabular}

a Results obtained for mixed samples (two cigarettes) of 20 brands, analyzed in triplicate.

\section{Statistical analysis}

Data exploration as well as calculation of descriptive statistics and ANOVA was performed with IBM SPSS Statistics for Windows, version 22.0 (IBM Corp., Armonk, NY). Significant differences were assumed at $\mathrm{p}<0.05$. For mathematical calculations, results below the LOD were imputed as the LOD divided by the square root of 2 .

\section{Results and discussion}

\section{Metals content in tobacco}

Twenty (20) cigarette brands were analyzed for their content in 11 metals. The results are summarized in Table 1. The decreasing order of metal content was $\mathrm{Al}>\mathrm{Mn}>\mathrm{Ba}>\mathrm{Zn}>\mathrm{Ni}>\mathrm{Cr}>\mathrm{Co}>\mathrm{Cd}>\mathrm{Pb}>\mathrm{As}>\mathrm{TI}$. Three groups were formed according to the average metal content. The first group (contents $>100 \mu \mathrm{g} / \mathrm{g})$ includes $\mathrm{Al}(667.2 \mu \mathrm{g} / \mathrm{g}), \mathrm{Mn}(148.4 \mu \mathrm{g} / \mathrm{g})$ and Ba $(123.0 \mu \mathrm{g} / \mathrm{g})$. In the second group (contents ranging between 1 and $100 \mu \mathrm{g} / \mathrm{g})$, it is included $\mathrm{Zn}(25.2 \mu \mathrm{g} / \mathrm{g}), \mathrm{Ni}(2.10 \mu \mathrm{g} / \mathrm{g})$ and $\mathrm{Cr}(1.39 \mu \mathrm{g} / \mathrm{g}$ ). The third cluster (contents $<1 \mu \mathrm{g} / \mathrm{g}$ ) includes Co $(0.84 \mu \mathrm{g} / \mathrm{g}), \mathrm{Cd}(0.79 \mu \mathrm{g} / \mathrm{g}), \mathrm{Pb}(0.54 \mu \mathrm{g} / \mathrm{g})$, As $(0.14 \mu \mathrm{g} / \mathrm{g})$ and TI $(0.074 \mu \mathrm{g} / \mathrm{g})$. The average metals content obtained in this study is in close agreement with the literature data $[17,19,21,25]$. See Table 1 for a detailed comparison between the values obtained in this study and data from literature.

\section{Metals transfer from tobacco to cigarette smoke}

The rate of metals transfer from tobacco to cigarette smoke was calculated based on the metal content in tobacco and cigarette ashes. The results are summarized in Table 2. It was observed that the rate of transference varies greatly depending on the metal. The highest rates were observed for $\mathrm{Tl}(85-92 \%)$ and Cd (81-90\%) and the lowest for $\mathrm{Al}(0.2-2.5 \%), \mathrm{Ba}(0.5-1.6 \%)$ and $\mathrm{Mn}(0.1-2.4 \%)$. Both $\mathrm{As}$ and $\mathrm{Pb}$ showed to pass to cigarette smoke at an intermediate extent (33-44\% and 46-60\%, respectively). These results are in good agreement with literature data. Nandi et al. [26] studied the Cd partition between cigarette ash and smoke and found that just $16 \%$ of Cd stays in the ash while $84 \%$ is volatilized. Kazi, Jalbani, Arain, Jamali, Afridi, Sarfraz and Shah [25] also studied the 
Table 2

Rate of metals transfer from tobacco to cigarette smoke (\%).

\begin{tabular}{llll}
\hline Element & Range $^{*}$ & Literature data & Reference \\
\hline $\mathrm{Al}$ & $0.2-2.5$ & $1.0-2.7$ & {$[25]$} \\
$\mathrm{As}$ & $33-44$ & $30-50$ & {$[17]$} \\
$\mathrm{Ba}$ & $0.5-1.6$ & 40 & {$[30]$} \\
$\mathrm{Cd}$ & & - & - \\
$\mathrm{Co}$ & $81-90$ & $84-85$ & {$[25]$} \\
$\mathrm{Cr}$ & $70-80$ & {$[17]$} \\
$\mathrm{Mn}$ & $1.8-9.5$ & 12.5 & {$[34]$} \\
& & 20 & {$[29]$} \\
$\mathrm{Ni}$ & $0.7-8.3$ & 50.2 & {$[29]$} \\
& $0.1-2.4$ & 5 & {$[25]$} \\
& & $56.3-65.5$ & {$[36]$} \\
$\mathrm{Pb}$ & $3.6-15.5$ & $2.8-8.7$ & {$[25]$} \\
& & $22.5-41.6$ & {$[31]$} \\
$\mathrm{Tl}$ & & $54.3-67.1$ & {$[32]$} \\
$\mathrm{Zn}$ & $46-60$ & $24.3-35.5$ & - \\
& & 37 & {$[33]$} \\
\hline
\end{tabular}

* Results obtained for mixed samples (two cigarettes) of 20 brands, analyzed in triplicate.

partition of $\mathrm{Cd}$ and other metals ( $\mathrm{Al}, \mathrm{Ni}$ and $\mathrm{Pb}$ ) between cigarette ash and smoke and found that only a small fraction of $\mathrm{Cd}$ is present in the ashes (15-31\%), while the remaining (69-85\%) passes into the smoke. Piadé et al. [17] also reported that $\mathrm{Cd}$ in ashes ranges between 20 and $30 \%$ of the total Cd present in the tobacco. For $\mathrm{Tl}$, no studies are available regarding its transfer from tobacco to cigarette smoke. However, the very high rates of Tl transfer to cigarette smoke obtained in this study (83-92\%) can be explained by its high volatility. In fact, Tl was included in the group of elements showing high volatility during coal combustion $[27,28]$ and thus it is expected that, during cigarette smoking, Tl greatly passes into the smoke fraction.

In our study, the lowest transfer rates were observed for $\mathrm{Al}, \mathrm{Ba}$ and Mn, as mentioned above. Kazi, Jalbani, Arain, Jamali, Afridi, Sarfraz and Shah [25] showed that, after smoking, most of the $\mathrm{Al}$ in tobacco in present in the ash (97.3-99.0\%) and that only a small fraction (1.0-2.7\%) actually passes to the smoke, which is in good agreement with our results $(0.2-2.5 \%)$. Ba and $\mathrm{Mn}$ also showed lower rates of transfer to cigarette smoke $(0.5-1.6 \%$ and $0.1-2.4 \%$, respectively). Comparison with literature data is not possible for Ba since no studies are available. For Mn, only one study reported the rate of transfer to cigarette smoke. In this particular study, most Mn was present in the ashes (95\%), and only 5\% showed to pass into the smoke [29]. Despite the lack of studies for these metals, it is plausible that most $\mathrm{Ba}$ and Mn stays in the cigarettes ash. These metals are in the list of non-volatile elements, being concentrated in the ash residues after coal combustion [27].

For the others metals analyzed, lower rates of transfer to cigarette smoke $(<10 \%)$ were generally observed. Three elements showed to be notable exceptions: As (33-44\%), $\mathrm{Pb}(46-60 \%)$ and $\mathrm{Zn}$ (13-21\%). Piadé et al. [17] reported that $30-50 \%$ of As and $\mathrm{Pb}$ present in tobacco passes to the smoke. Other studies reported similar values for As (40\%) [30] and for $\mathrm{Pb}(24-37 \%$ ) [31,32]. For Zn, two studies reported values ranging from 7.6 to $18.5 \%[33,34]$, which is slightly below the range obtained in this study (13-21\%).

The temperature at the tip of a cigarette that burns may reach $900^{\circ} \mathrm{C}$, and this temperature is high enough to pass most metals into the gas phase [35]. The chemical species of each element actually present in tobacco greatly affect its volatility (and therefore its transfer rate to the gas phase). For instance, most Cd seems to be present in tobacco as part of organic molecules and thus it is volatilized at lower temperatures, compared to the inorganic
Table 3

Metals content in lung tissue ( $\mu \mathrm{g} / \mathrm{g}$, dry weight; mean $\pm \mathrm{SD}$ ).

\begin{tabular}{lll}
\hline Element & Smokers $(\mathrm{n}=24)$ & Non-smokers $(\mathrm{n}=38)$ \\
\hline $\mathrm{Al}$ & $97.8 \pm 94.4$ & $78.2 \pm 68.9$ \\
As $^{*}$ & $0.089 \pm 0.034$ & $0.043 \pm 0.022$ \\
$\mathrm{Ba}$ & $0.48 \pm 0.45$ & $0.33 \pm 0.24$ \\
$\mathbf{C d}^{*}$ & $0.68 \pm 0.44$ & $0.074 \pm 0.062$ \\
$\mathrm{Co}$ & $0.076 \pm 0.064$ & $0.065 \pm 0.052$ \\
$\mathrm{Cr}$ & $1.25 \pm 1.37$ & $0.63 \pm 0.47$ \\
$\mathrm{Mn}$ & $0.55 \pm 0.71$ & $0.32 \pm 0.19$ \\
$\mathrm{Ni}$ & $0.66 \pm 0.93$ & $0.38 \pm 0.42$ \\
$\mathbf{P b}$ & $0.32 \pm 0.26$ & $0.11 \pm 0.09$ \\
$\mathrm{Tl}$ & $0.002 \pm 0.001$ & $0.002 \pm 0.001$ \\
$\mathrm{Zn}$ & $30.6 \pm 15.2$ & $27.5 \pm 8.7$ \\
\hline
\end{tabular}

* Statistically different at $\mathrm{p}<0.05$.

forms of this element. By contrary, As and $\mathrm{Pb}$ are usually present in their inorganic and non-volatile form, which explains their higher content in cigarette ashes compared to Cd [17]. The same is also observed for $\mathrm{Ni}$, where most of its content remains in the ashes after cigarette burning $[17,36]$.

Evidences of metals exposure from cigarette smoke in lung tissues

The lung tissue of 77 adults (24 smokers and 38 non-smokers) was analyzed for their content in 11 metals. The results are summarized in Table 3. The lung tissue of smokers showed a higher content of the 11 analyzed elements compared to the lung tissue of nonsmokers. Significant higher levels of $\mathrm{As}, \mathrm{Cd}$ and $\mathrm{Pb}$ were found in smokers' lung tissue. The As level was twice as high in the smokers compared to non-smokers $(0.089 \pm 0.034 v s$. $0.043 \pm 0.022 \mu \mathrm{g} / \mathrm{g})$. For $\mathrm{Pb}$, mean level was three times higher in smokers than nonsmokers $(0.32 \pm 0.26$ vs. $0.11 \pm 0.09 \mu \mathrm{g} / \mathrm{g})$. For $\mathrm{Cd}$, the difference was even more noticeable. The $\mathrm{Cd}$ level was almost ten times higher in the lung tissue of smokers compared to non-smokers $(0.68 \pm 0.44$ vs. $0.074 \pm 0.062 \mu \mathrm{g} / \mathrm{g}$ ). Thus, it is evident that smoking influences the content of $\mathrm{As}, \mathrm{Cd}$ and $\mathrm{Pb}$ in the lung tissue. These results are in good agreement with literature data. Paakko, Kokkonen, Anttila and Kalliomaki [37] determined the Cd and $\mathrm{Cr}$ levels in the lung tissue of 45 individuals and found that $\mathrm{Cd}$ was significantly higher in smokers than non-smokers $(3.0 \pm 2.2 v s .0 .4 \pm 0.4 \mu \mathrm{g} / \mathrm{g})$. More recently, De Palma, Goldoni, Catalani, Carbognani, Poli, Mozzoni, Acampa, Internullo, Rusca and Apostoli [38] determined the levels of several metals, including $\mathrm{As}, \mathrm{Cd}$ and $\mathrm{Pb}$, in the lung tissue of patients affected by lung cancer and found that the content of $\mathrm{Cd}$ and $\mathrm{Pb}$ was significantly higher in smokers. $\mathrm{As}, \mathrm{Cd}$ and $\mathrm{Pb}$ are well-recognized toxic elements - As and Cd have been classified in Group 1 ("Carcinogenic to humans") and inorganic $\mathrm{Pb}$ in Group 2A ("probably carcinogenic") by IARC $[12,14,16]$. Thus, smokers have an increased risk of developing lung diseases due to exposure to these metals present in tobacco.

Besides As, $\mathrm{Cd}$ and $\mathrm{Pb}$, other metals, especially those that are strongly inflammation-inducing and sensitizing, such as $\mathrm{Cr}, \mathrm{Co}, \mathrm{Ni}$, can play an important role in the etiology of lung diseases. Recently, tobacco smoking has been associated with interstitial lung disease, a large group of disorders characterized by progressive scarring of the lung tissue between and supporting the air sacs $[39,40]$. In our study, a higher content of $\mathrm{Cr}$, Co and $\mathrm{Ni}$ was observed in the lung tissue of smokers compared to non-smokers $(1.25 \pm 1.37 \mathrm{vs}$. $0.63 \pm 0.47 \mu \mathrm{g} / \mathrm{g}$ for $\mathrm{Cr}, 0.076 \pm 0.064 v s .0 .065 \pm 0.052 \mu \mathrm{g} / \mathrm{g}$ for Co and $0.66 \pm 0.93$ vs. $0.38 \pm 0.42 \mu \mathrm{g} / \mathrm{g}$ for $\mathrm{Ni}$ ), proving that smoking can be an important source of human exposure to toxic metals. 


\section{Conclusion}

Tobacco contains important amounts of a wide range of metals potentially harmful to human health. The transfer rate of metals to cigarette smoke varies greatly depending on the element. The higher transfer rates were observed for $\mathrm{Tl}$ and $\mathrm{Cd}$, followed by $\mathrm{Pb}$ and As. It was found that $\mathrm{As}, \mathrm{Cd}$ and $\mathrm{Pb}$ levels were significantly higher in the lung tissue of smokers compared to non-smokers, proving that, besides systemic effects, smoking results in a significant increase of these metals in that tissue. Since it is well-known that these metals are highly toxic, and in particular are known or presumed human carcinogens, this study shows that they may represent an important contribution to the overall carcinogenic potential of cigarette smoke and stresses the importance of public health measures aiming at to reduce smoking habits and exposure to second-hand smoke. This study also provides updated information on metals levels in tobacco and cigarette smoke, and new data for some elements that have not been yet evaluated (ex. Ba and $\mathrm{Tl}$ ). Finally, strong evidence of the marks that smoking leaves in the lungs of smokers is provided.

\section{References}

[1] WHO, WHO global report: mortality attributable to tobacco, (2012)

[2] WHO, WHO global report on trends in prevalence of tobacco smoking 2015, (2015).

[3] P. Jha, Avoidable deaths from smoking: a global perspective, Public Health Rev. 33 (2012) 569-600.

[4] WHO, Global Atlas on cardiovascular disease prevention and control, (2011).

[5] HHS, U.S. Department of Health and Human Services, How Tobacco Smoke Causes Disease: The Biology and Behavioral Basis for Smoking-Attributable Disease: A Report of the Surgeon General, GA, U.S. Department of Health and Human Services, Centers for Disease Control and Prevention, National Center for Chronic Disease Prevention and Health Promotion, Office on Smoking and Health, Atlanta, 2010.

[6] IARC, Tobacco smoke and involuntary smoking, IARC Monogr. Eval. Carcinog. Risks Hum. 83 (2004) 1-1452.

[7] A. Rodman, T.A. Perfetti, The Chemical Components of Tobacco and Tobacco Smoke, 2nd ed., CRC Press, 2013.

[8] D. Bernhard, A. Rossmann, G. Wick, Metals in cigarette smoke, Iubmb Life 57 (2005) 805-809

[9] R.V. Caruso, R.J. O'Connor, W.E. Stephens, K.M. Cummings, G.T. Fong, Toxic metal concentrations in cigarettes obtained from U.S. smokers in 2009: results from the international tobacco control (ITC) United States survey cohort, Int. J. Environ. Res. Public Health 11 (2014) 202-217.

[10] E. Pinto, I.M.P.L.V.O. Ferreira, Cation transporters/channels in plants: tools for nutrient biofortification, J. Plant Physiol. 179 (2015) 64-82.

[11] U. Kramer, Metal hyperaccumulation in plants, Annu. Rev. Plant Biol. 61 (2010) 517-534.

[12] IARC, Arsenic and arsenic compounds (group 1), IARC monographs on the evaluation of carcinogenic risks to humans, Supplement 7 (84) (1987) $100-106$.

[13] IARC, Nickel and nickel compounds, IARC monographs on the evaluation of carcinogenic risks to humans, 49 (1990) 257-445.

[14] IARC, Cadmium and cadmium Compounds, IARC Monographs on the Evaluation of Carcinogenic Risks to Humans, 58 (1993) 119-237.

[15] IARC, Chromium and chromium compounds, IARC monographs on the evaluation of carcinogenic risks to humans, 49 (1990) 49-256.

[16] IARC, Inorganic and organic lead compounds, IARC Monogr. Eval. Carcinog. Risks Hum. 87 (2006) 1-529.

[17] J.J. Piadé, G. Jaccard, C. Dolka, M. Belushkin, S. Wajrock, Differences in cadmium transfer from tobacco to cigarette smoke, compared to arsenic or lead, Toxicol. Rep. 2 (2015) 12-26.

[18] M.J. Chang, K. Walker, R.L. McDaniel, C.T. Connell, Impaction collection and slurry sampling for the determination of arsenic, cadmium, and lead in sidestream cigarette smoke by inductively coupled plasma-mass spectrometry, J. Environ. Monit. 7 (2005) 1349-1354.

[19] M.R. Fresquez, R.S. Pappas, C.H. Watson, Establishment of toxic metal reference range in tobacco from US cigarettes, J. Anal. Toxicol. 37 (2013) 298-304.

[20] R.S. Pappas, M.R. Fresquez, N. Martone, C.H. Watson, Toxic metal concentrations in mainstream smoke from cigarettes available in the USA, J. Anal. Toxicol. 38 (2014) 204-211.

[21] M. Chiba, R. Masironi, Toxic and trace elements in tobacco and tobacco smoke, Bull. World Health Organ. 70 (1992) 269-275.

[22] M.L. Goniewicz, J. Knysak, M. Gawron, L. Kosmider, A. Sobczak, J. Kurek, A. Prokopowicz, M. Jablonska-Czapla, C. Rosik-Dulewska, C. Havel, P. Jacob, N. Benowitz, Levels of selected carcinogens and toxicants in vapour from electronic cigarettes, Tob. Control 23 (2014) 133-139.

[23] M. Williams, A. Villarreal, K. Bozhilov, S. Lin, P. Talbot, Metal and silicate particles including nanoparticles are present in electronic cigarette cartomizer fluid and aerosol, PLoS One 8 (2013) e57987.

[24] N.M. Hepp, W.R. Mindak, J. Cheng, Determination of total lead in lipstick: development and validation of a microwave-assisted digestion inductively coupled plasma-mass spectrometric method, J. Cosmet. Sci. 60 (2009) 405-414.

[25] T.G. Kazi, N. Jalbani, M.B. Arain, M.K. Jamali, H.I. Afridi, R.A. Sarfraz, A.Q. Shah, Toxic metals distribution in different components of Pakistani and imported cigarettes by electrothermal atomic absorption spectrometer, J. Hazard. Mater. 163 (2009) 302-307.

[26] M. Nandi, D. Slone, H. Jick, S. Shapiro, G.P. Lewis, Cadmium content of cigarettes, Lancet 2 (1969), 1329-\&.

[27] M.A.L. Anton, D.A. Spears, M.D. Somoano, M.R.M. Tarazona, Thallium in coal: analysis and environmental implications, Fuel 105 (2013) 13-18.

[28] WHO, Environmental health criteria 182-Thallium, The International Programme on Chemical Safety (IPCS), (1996) http://www.inchem.org/ documents/ehc/ehc/ehc182.htm.

[29] S. Ahmad, M.S. Chaudhry, I.H. Qureshi, Determination of toxic elements in tobacco products by instrumental neutron-activation analysis, J. Radioanal. Chem. 54 (1979) 331-341.

[30] R.A. Nadkarni, Some considerations of metal content of tobacco products, Chem. Ind. 17 (1970) 693-696.

[31] K. Kalcher, W. Kern, R. Pietsch, Cadmium and lead in the smoke of a filter cigarette, Sci. Total Environ. 128 (1993) 21-35.

[32] M. Galazyn-Sidorczuk, M.M. Brzoska, J. Moniuszko-Jakoniuk, Estimation of Polish cigarettes contamination with cadmium and lead, and exposure to these metals via smoking, Environ. Monit. Assess. 137 (2008) 481-493.

[33] E.E. Menden, L.W. Michael, H.G. Petering, V.J. Elia, Distribution of cadmium and nickel of tobacco during cigarette-smoking, Environ. Sci. Technol. 6 (1972), 830-\&.

[34] A. Nada, M. Abdel-Wahab, A. Sroor, A.S. Abdel-Haleem, M.F. Abdel-Sabour, Heavy metals and rare earth elements source-sink in some Egyptian cigarettes as determined by neutron activation analysis, Appl. Radiat. Isotopes 51 (1999) 131-136.

[35] R.R. Baker, Temperature distribution inside a burning cigarette, Nature 247 (1974) 404-406.

[36] W. Torjussen, H. Zachariasen, I. Andersen, Cigarette smoking and nickel exposure, J. Environ. Monit. 5 (2003) 198-201.

[37] P. Paakko, P. Kokkonen, S. Anttila, P.L. Kalliomaki, Cadmium and chromium as markers of smoking in human-lung tissue, Environ. Res, 49 (1989) 197-207.

[38] G. De Palma, M. Goldoni, S. Catalani, P. Carbognani, D. Poli, P. Mozzoni, O. Acampa, E. Internullo, M. Rusca, P. Apostoli, Metallic elements in pulmonary biopsies from lung cancer and control subjects, Acta Bio-Med.: Atenei Parmensis 79 (Suppl. 1) (2008) 43-51

[39] R.S. Pappas, Toxic elements in tobacco and in cigarette smoke: inflammation and sensitization, Metallomics 3 (2011) 1181-1198.

[40] R.N. Rao, L.R. Goodman, J.F. Tomashefski, Smoking-related interstitial lung disease, Ann. Diagn. Pathol. 12 (2008) 445-457. 